\title{
MANAJEMEN DANA IURAN RUKUN KEMATIAN DI PUNTUN KOTA PALANGKA RAYA Jirhanuddin $^{1}$, Ahmad Dakhoir, ${ }^{2}$ dan Sulistyaningsih ${ }^{3}$
}

\section{abstract}

The existence of rukun kematian (RKM) nowadays is extremely helpful for the society. Therefore, it needs a good management in order to make RKM running well and functioning as the purpose when it was established. However, the result of observation toward RKM Puntun, Palangka Raya showed several inexpediencies about the application of management elements and the distribution of compensation that given by RKM. Then this research discussed about funding management and compensation practices by RKM to its member. There were two problems of the study: (1) How is the funding management in RKM in Puntun, Palangka Raya, (2) Is the distribution of compensation appropriate with ta'awun principal.

This research used qualitative-descriptive approach which the object of the study was funding management of RKM Puntun, Palangka Raya and appropriate distribution of compensation with ta'awun principal. Meanwhile, the subject of the study consisted of 3 board members. Collecting data method was used observation, interview, and documentation. Whereas, data validation was proven with triangulation technique then analyzed with collection, reduction, display, and conclusion method.

Through various reference of theory that was used in order to support the study. The result of funding management of RKM Puntun, Palangka Raya was not fully applied the management elements. Afterwards, the distribution of compensation of RKM was not fully applied ta'awun principal as well. This can be seen when parties from RKM provides a perind for 3 months against members of the new register, in a period of 3 months before new members receive accident (died), then the member is not entitled to receive compensation from the RKM.

Keywords : rukun kematian, management,ta'awun.

\section{A. Pendahuluan}

\section{Latar Belakang}

Al-Qur'an menegaskan bahwa segala sesuatu yang bernyawa dimuka bumi ini akan menemui kematian hal ini sesuai dengan firman Allah SWT yang berbunyi:

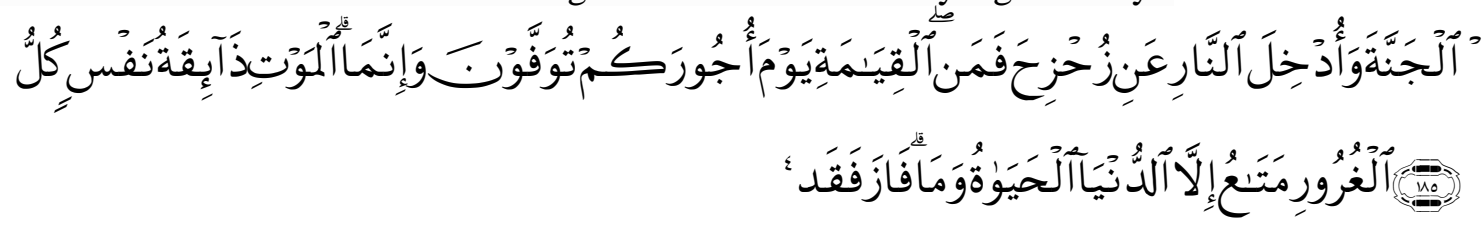

\footnotetext{
${ }^{1}$ Direktur Pasca Sarjana.

${ }^{2}$ Wakil Dekan Bidang Akademik Dan Pengembangan Lembaga.

${ }^{3}$ IAIN Palangka Raya,

${ }^{4}$ Depertemen Agama, Al-Qur'an dan Terjemahnya, Semarang :Tanjung Mas Inti Semarang, 1992.h.109.
} 
Artinya:"Tiap-tiap yang berjiwa akan merasakan mati. dan Sesungguhnya pada hari kiamat sajalah disempurnakan pahalamu. Barangsiapa dijauhkan dari neraka dan dimasukkan ke dalam syurga, Maka sungguh ia telah beruntung. kehidupan dunia itu tidak lain hanyalah kesenangan yang memperdayakan”.

Bagi manusia yang masih hidup ada kegiatan yang wajib dilaksanakan terkait dengan jenazah, mencakup memandikan, mengkafani, menshalatkan, dan menguburkan. Semua kegiatan tersebut memerlukan perlengkapan dan perisapan biaya atau dana. Selanjutnya, dari tahun ke tahun harga kain kafan, wewangian hingga tanah pemakaman harganya semakin naik. Sehingga untuk menguburkan jenazah kita harus mengeluarkan biaya yang tidak sedikit.

Manusia tidak mengetahui kapan kematian akan datang dan dalam keadaan ekonomi seperti apa manusia akan menemui ajal. Jika kematian datang ketika manusia dalam keadaan ekonomi yang berada, tentu tidak akan menimbulkan permasalahan. Sebaliknya, permasalahan akan muncul ketika kematian datang pada saat manusia mengalami kesulitan ekonomi, terlebih bagi masyarakat yang tinggal diperkotaan. ${ }^{5}$

Islam senantiasa memberikan jaminan kepada umatnya dan orang-orang yang bernaung di bawah naungan kekuasaannya. Jaminan itu bisa melalui solidaritas sosial diantara umat Islam, dan bisa pula lewat pemerintah dan baitul mal. Baitul mal itu sendiri merupakan lembaga asuransi umum bagi setiap orang yang bernaung di bawah pemerintahan Islam. ${ }^{6}$ Sedangkan dikalangan masyarakat sekarang, bentuk solidaritas sosial yang dimiliki oleh Islam yaitu sebuah lembaga rukun kematian. Lembaga tersebut membantu meringankan beban keluarga yang ditinggalkan dengan cara memberikan santunan dari hasil iuaran yang dilakukan oleh anggota rukun kematian.

Manajemen diperlukan oleh sebuah organisasi agar pencapaian tujuan dapat berjalan secara efektif dan efesien. Efektif, artinya menyelesaikan kegiatan-kegiatan sehingga dapat mencapai sasaran organisasi. Efesien berarti memperoleh output terbesar dengan input terkecil. $^{7}$ Agar tercapainya manajemen yang baik maka harus sesuai dengan perencanaan, pengorganisasian, menggerakkan, dan pengendalian. Namun, hal tersebut berbeda dengan manajemen RKM yang berada di Puntun, yang mana mereka tidak sepenuhnya menerapkan unsur-unsur manajemen. Selain itu, Berdasarkan observasi awal yang telah dilakukan di Puntun (Palangka Raya), penulis menemukan bahwa sistem pelaksanaan pemberian hasil iuran kepada keluarga anggota dari rukun kematian yang ada di sana terjadi ketidak-adilan, ketidak-adilan itu terpapar ketika ada anggota baru yang keluarganya meninggal dunia, maka anggota tersebut tidak bisa mengklaim atau memperoleh santunan dari rukun kematian tersebut kecuali setelah tiga bulan keanggotaanya. ${ }^{8}$

Berdasarkan hal tersebut menurut penulis, jika dilihat dari tujuan didirikannya rukun kematian adalah untuk membantu meringankan beban keluarga yang ditinggalkan dan prinsip

\footnotetext{
${ }^{5}$ Anna Maria Faulina, Rukun Kemtaian dalam Predpektif Asuransi Syariah Pada

BeberapaMesjidDanYayasan,http://repository.uinjkt.ac.id/dspace/bitstream/123456789/25070/1/Anna\%20Mari a\%20Faulina.pdf.Diakses tanggal 21 Februari 2016.

${ }^{6}$ Andri Soemitra, Bank \& Lembaga Keuangan Syariah, Jakarta: Kencana Prenada Media Group, 2014, h.261.

${ }^{7}$ Nana Herdiana Abdurrahman, Manajemen Bisnis Syariah \& Kewirausahaan, Bandung: Pustaka Setia, 2013, h.48.

${ }^{8}$ wawancara dan observasi terhadap subjek MI pada tanggal 1April 2016.
} 
utama dari rukun kematian adalah tolong-menolong (ta'awun). Berdasarkan uraian diatas penulis tertarik untuk meneliti dan merangkumnya dalam sebuah judul "MANAJEMEN DANA IURAN RUKUN KEMATIAN DI PUNTUN KOTA PALANGKA RAYA".

\section{B. Landasan Teori}

1. Manajemen Islam

a. Pengertian Manajemen Islam

Manajemen dalam bahasa Arab disebut dengan idarah diambil dari perkataan adartasy-syai'i atau perkataan 'adarta bihi juga dapat didasarkan pada kata addauran. Oleh karena itu, dalam Elias' Modern Dictionary English Arabic kata management, sepadan dengan kata tadbir, idarah, siyasah dan qiyadah dalam bahasa Arab. ${ }^{9}$

Hal yang paling penting dalam manajemen berdasarkan pandangan-pandangan Islam adalah harus ada sifat ri'ayah atau jiwa kepemimpinan. Kepemimpinan menurut pandangan Islam merupakan faktor utama dalam konsep manajemen. Watak dasar ini merupakan bagian penting dari manusia sebagai khalifah fi al$\operatorname{ar} \square l .^{10}$

Manajemen (al-idarah) menurut pandangan Islam merupakan manajemen yang adil. Batasan adil adalah pemimpin tidak menganiaya bawahan dan bawahan tidak merugikan perusahaan. Bentuk penganiayaan yang dimaksudkan adalah mengurangi atau tidak memberikan hak bawahan dan memaksa bawahan untuk bekerja melebihi ketentuan. Jika seorang manajer mengharuskan bawahannya bekerja melampaui waktu kerja yang ditentukan, maka sebenarnya manajer itu telah mendzalimi bawahannya. hal ini sangat ditentang oleh Islam. ${ }^{11}$

Islam juga menekankan pentingnya unsur kejujuran dan kepercayaan dalam manajemen. Nabi Muhammad Saw adalah seorang yang sangat terpercaya dalam menjalankan manajemen bisnisnya. Manajemen yang dicontohkan Nabi Muhammad Saw adalah menempatkan manusia sebagai postulanya atau sebagai fokusnya, bukan hanya sebagai faktor produksi yang semata diperas tenaganya untuk mengejar target produksi. $^{12}$

Agama Islam menjelaskan bahwa segala sesuatu yang akan dikerjakan itu harus jelas, yaitu jelas apa yang akan dikerjakan (halal), jelas cara mengerjakannya (tidak menghalalkan segala cara), dan jelas apa yang akan dihasilkan dan manfaatnya (benar dan adil). Inilah yang ditetapkan dalam manajemen syariah. Manajemen dalam arti mengetur sesuatu agar melakukan dengan baik, tepat, dan terarah merupakan sesuatu yang disyaratkan ajaran Islam. Adapun manajemen Syariah adalah seni mengelola sumber daya yang dimiliki dengan tambahan sumber daya dan metode syariah yang tercantum dalam Al-Qur'an atau hadis Nabi. ${ }^{13}$

\section{b. Ciri-ciri Manajemen Islami}

\footnotetext{
${ }^{9}$ Muhammad, Manajemen Dana Bank Syariah, Yogyakarta: Ekonisia, 2005, h.13.

${ }^{10}$ Abdul Aziz, Manajemen Investasi Syariah, bandung: Pustaka Alfabeta, 2010.h.22.

${ }^{11}$ Ibid.,

${ }^{12}$ Ibid.,

${ }^{13}$ Nana Herdiana Abdurrahman, Manajemen Bisnis...,h.21.
} 
Ciri-ciri Islami, menurut Effendy menjelaskan ada enam ciri sebagai berikut: ${ }^{14}$

1) Manajemen berdasarkan akhlak yang luhur

Akhlak mulia merupakan nilai fundametal dalam ajara Islam, bahkan kehadiran Islam yang dibawa Rasulullah adalah menyempurnakan akhlak manusia. Untuk itu, para pemimpin atau manejer harus mengamalkan akhlak mulia atau luhur (jujur, adil, sabar, rendah hati, amanah, saling menghormati, dll), dan penyelenggaraan manajemen dalam organisasi tentu saja harus berpedoman kepada prilaku akhlak karimah.

2) Manajemen terbuka

Manajemen Islam sangat memperhatikan keterbukaan, karena berkaitan dengan nilai kejujuran, pengelolaan yang sehat, dan terbuka (open minded) atau tranparansi. Karena jabatan sebagai pemimpin atau manajer adalah amanah yang harus dipelihara dengan baik dan penuh keadilan. Berikut firman Allah SWT:

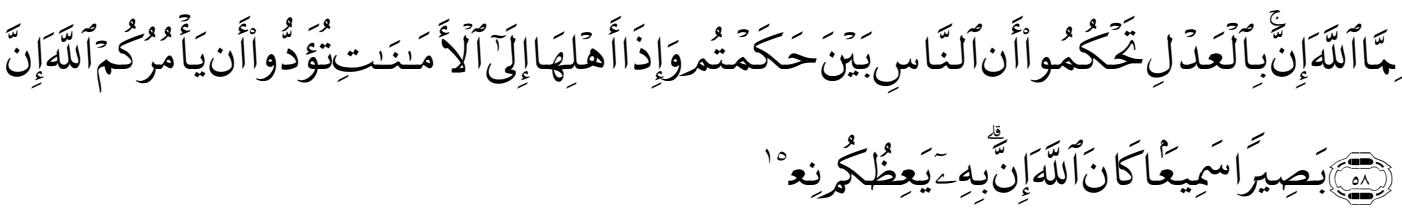

Artinya:"Sesungguhnya Allah menyuruh kamu menyampaikan amanat kepada yang berhak menerimanya, dan (menyuruh kamu) apabila menetapkan hukum di antara manusia supaya kamu menetapkan dengan adil. Sesungguhnya Allah memberi pengajaran yang sebaik-baiknya kepadamu. Sesungguhnya Allah adalah Maha mendengar lagi Maha melihat."( QS. An-Nisa ayat 58)

Seorang manajer muslim yang menjalankan manajemen Islami adalah orang yang memiliki sifat jujur dan terbuka setiap saat untuk diperiksa apa yang dikerjakannya untuk orgaisasi dalam rangka kebaikan umat.

3) Manajemen yang demokrasi

Konsekuensi dari sikap terbuka dalam manajemen, maka pengambilan keputusan atas musyawarah untuk kebaikan organisasi. Bahkan dengan musyawarah, setiap personil akan merasa bertanggung jawab dan memiliki komitmen dalam menjalankan semua keputusan. Firman Allah dalam surat Ali-Imran ayat 159.

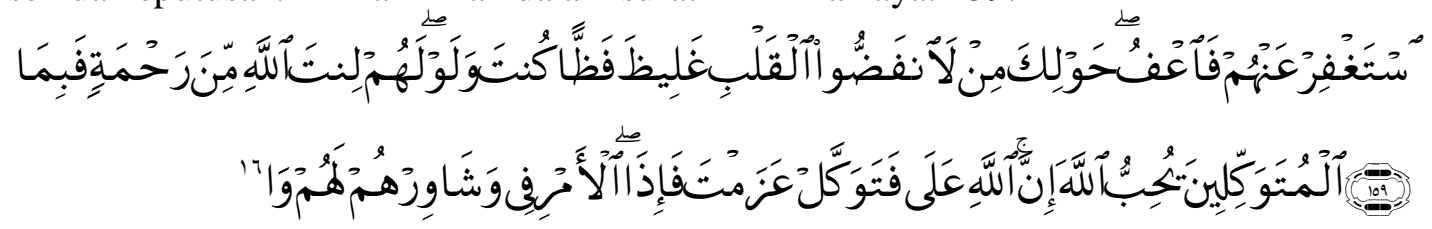

Artinya:"Maka disebabkan rahmat dari Allah-lah kamu Berlaku lemah lembut terhadap mereka. Sekiranya kamu bersikap keras lagi berhati kasar, tentulah mereka menjauhkan diri dari sekelilingmu. karena itu ma'afkanlah mereka, mohonkanlah ampun bagi mereka, dan bermusyawaratlah dengan mereka dalam urusan itu. kemudian apabila kamu telah membulatkan tekad, Maka

\footnotetext{
${ }^{14}$ Syafaruddin, Manajemen Lembaga Pendidikan Islam, Ciputat: Ciputat Press, 2005, h.198.

${ }^{15}$ Departemen Agama, Al-Qur'an dan Terjemahnya..., h.128

${ }^{16}$ Ibid..., h. 103
} 
bertawakkallah kepada Allah. Sesungguhnya Allah menyukai orang-orang yang bertawakkal kepada-Nya".

Dengan semakin tinggi keterlibatan anggota dalam menjalankan pekerjaannya dan mendorong munculnya kepuasan kerja dengan dibarengi imbalan yang sesuai degan kebutuhan hidup, kemampuan organisasi dan ketentuan yang berlaku.

4) Manajemen berdasarkan ilmiah

Agama Islam menjelaskan bahwa setiap pekerjaa harus dikerjakan dengan dasar pengetahuan atau kebenaran. Karena itu, aktivitas manajemen yang dijalankan oleh pemimpin atau manajer organisasi haruslah mengamalkan prinsip pengetahuan. Berikut firman Allah SWT:

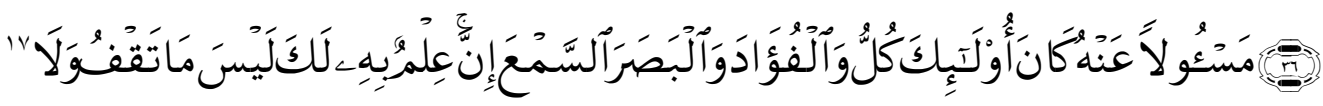

Artinya:"dan janganlah kamu mengikuti apa yang kamu tidak mempunyai pengetahuan tentangnya. Sesungguhnya pendengaran, penglihatan dan hati, semuanya itu akan diminta pertanggungan jawabnya."( QS.Al-Isra ayat 36).

5) Manajemen berdasarkan tolong-menolong (ta'awun)

Salah satu ciri utama kehidupan muslim berdasarkan ajaran Islam adalah prinsip ta'awun $^{18}$. Dalam Al-Qur'an Allah menjelaskan:

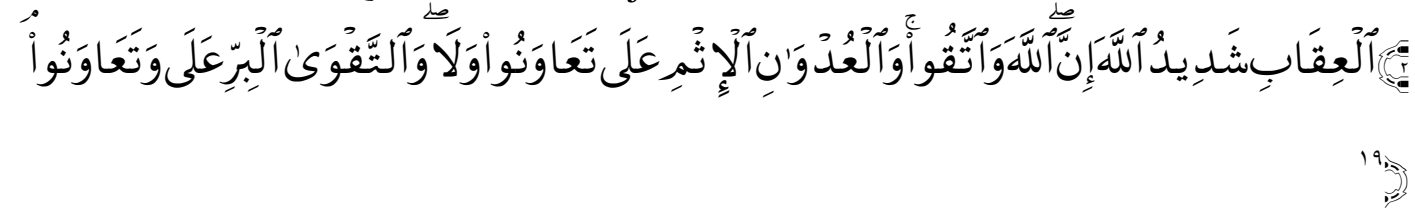

Artinya:"Dan tolong-menolonglah kamu dalam (mengerjakan) kebajikan dan takwa, dan jangan tolong-menolong dalam berbuat dosa dan pelanggaran. dan bertakwalah kamu kepada Allah, Sesungguhnya Allah Amat berat siksa-Nya." ( Al-Maidah ayat 2)

Mengamalkan prinsip tolong-menolong atau kerjasama adalah mengamalkan sunnatullah, dan hal itu sejalan dengan fitrah penciptaan manusia. Bahwa manusia diciptakan antara satu dengan yang lain memiliki kelebihan dan kekurangan,sehingga ada yang menjadi pemimpin dan ada yang menjadi anggota untuk memenuhi kebutuhan manusia. Bagaimanapun, kebutuhan hidup yang harus dipenuhi mencakup bidang ekonomi, politik, budaya, pendidikan dan keagamaan. Jadi prinsip ta'awun adalah sesuai fitrah manusia dalam menjalankan hidupnya sebagai makhluk sosial yang diciptakan Allah SWT.

6) Manajemen berdasarkan perdamaian

Allah memerintahkan umat Islam untuk selalu memelihara perdamaian, sesuai dengan hakikat Islam yang berisikan keselamatan dan kedamaian. Dalam aktivitas

\footnotetext{
${ }^{17}$ Departemen Agama, Al-Qur'an dan Terjemahnya...,h.429.

${ }^{18}$ Ta'awun artinya sikap tolong-menolong, bantu-membantu, dan bahu-membahu antara satu dengan yang lainnya.

${ }^{19}$ Departemen Agama, Al-Qur'an dan Terjemahnya...,h. 156
} 
apapun, termasuk manajemen dalam organisasi. Umat Islam harus mengamalkan dan menciptakan suasana perdamaian dan keharmonisan, karena hanya dengan iklim seperti itu, berbagai usaha dan kegiatan akan dapat dijalankan dalam mencapai tujuan yang diinginkan,yaitu mencapai kebahagian hidup di dunia menuju kebahagian akhirat.

2. Rukun Kematian

Rukun kematian adalah suatu organisasi atau wadah kegiatan sosial yang memberikan pelayanan pada warga perumahan yang menjadi anggotanya, dimana pelayanan yang diberikan kepada para anggotanya berupa pelayanan jasa kematian seperti, perawatan jenazah (memandikan, mengafankan, serta melakukan sholat jenazah), sampai pada pengantaran jenazah ke pemakaman dan pengurusan pemakamannya. Dalam melakukan perananya pada para anggotanya, pengurus rukun kematian (RKM) secara bersama-sama dengan warga lainnya bahu-membahu melakukan pelayanan kepada mereka yang mendapat musibah di bawah koordinasi pengurus rukem. ${ }^{20}$

Rukun kematian sangat bermanfaat bagi masyarakat, karena dengan adanya rukun kematian ini dapat membantu mengurangi beban keluarga yang ditinggalkan. Selain itu, rukun kematian juga dapat mempererat silaturahmi antara warga.

3. Ta'awun

Ta'awun adalah tolong-menolong sesama umat muslim dalam kebaikan. Ta'awun bisa dilakukan dimana saja dan kapan saja asalkan kita melihat saudara kita yang butuh pertolongan dan siap untuk menolongnya. Ta'awun tak seharusnya dipermasalahkan tentang siapa yang menolong dan siapa yang ditolong, terutama jika melihat dalam derajat, pangkat, dan harta duniawi. Ta'awun yang utama dilakukan dalam kebaikan dan bukan dalam keburukan. ${ }^{21}$

Salah satu prinsip yang menjadi landasan etika dalam muamalah secara Islami adalah ta'awun. Ta'awun merupakan salah satu prinsip utama dalam interaksi muamalah. Bahkan ta'awun dapat menjadi pondasi dalam membangun sistem ekonomi yang kokoh, agar pihak yang kuat dapat membantu yang lemah, masyarakat yang kaya memperhatikan yang miskin dan seterusnya. ${ }^{22}$ Ta'awun merupakan konsep dasar yang dijadikan asas untuk mengaplikasikan teori Islam atas harta, tanpa adanya ta'awun maka teori tersebut tidak dapat diwujudkan. Dan tanpa adanya pemahaman yang benar tentang makna ta'awun dan keimanan yang mendalam, maka kehidupan masyarakat Islam tidak akan pernah terbangun, dan konsep ekonominya hanya sebatas retorika. ${ }^{23}$

Ciri khas ajaran Islam adalah kebersamaan dalam segala aktivitas positif baik dalam melaksanakan ibadah ritual maupun dalam melaksanakan ibadah ritual maupun dalam melaksanakan aneka aktivitas. Itu sebabnya sholat berjamaah lebih diutamakan daripada shalat sendirian. Kebersamaaan lahir karena adanya tujuan dan kepentingan bersama serta saling percaya antar mereka yang bekerja sama. Karena itu semua pihak

\footnotetext{
${ }^{20}$ Mochnurrochman,RukemAl Ikhlas, http://rukemalikhlas.blogspot.co.id/2014/01/sekilas-tentangrukun-kematian-rukem-al.html. diakses tanggal 21 April 2016.

${ }^{21}$ Bimbie.com, Ta'awun sebuah pengertian dan manfaat, http://www.bimbie.com/manfaattaawun.htm.diakses tanggal 23 mei 2016.

${ }^{22}$ Muhammad Syakir Sula, Asuransi Syariah Konsep dan Sistem Operasional, Jakarta: Gema Insani, 2004.h.736.

${ }^{23}$ Baitul Maal Abdurahman bin auf, Konsep Ta'awun dalam Islam, http://www.baitulmaal.com/konsep-taawun-dalam-islam/.diakses tanggal 23 mei 2016.
} 
harus menunjukkan perhatian kepada yang lain, seperti hadis nabi saw, yang melukiskan hubungan sesama mukmin: ${ }^{24}$

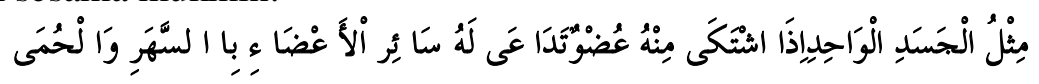

Bagaikan satu jasad yang bila salah satu organnya mearasakan keluhan, maka seluruh anggota tubh tak dapat tidur dan merasa demam" (HR. Bukhari dan Muslim melalui An-Nu'man bin Basyir).

Selain itu, perintah untuk saling tolong-menolong juga ditegas dalam Al-Qur'an salah satunya tercantum dalam surah Al-maidah ayat 5 yang berbunyi:

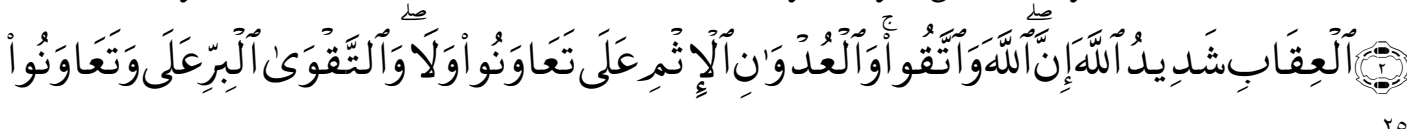

Artinya:"dan tolong-menolonglah kamu dalam (mengerjakan) kebajikan dan takwa, dan jangan tolong-menolong dalam berbuat dosa dan pelanggaran. dan bertakwalah kamu kepada Allah, Sesungguhnya Allah Amat berat siksa-Nya". Adapun faedah atau manfaat dari ta' awun adalah sebagai berikut:

1) Dengan tolong-menolong, pekerjaan dapat diselesaikan dengan lebih sempurna. Sehingg jika ada kekurangan, maka yang lain dapat menutupinya.

2) Dengan ta'awun dakwah akan lebih sempurna dan tersebar.

3) Ta'awun dan berpegang teguh kepada al-jama'ah adalah perkara ushul (pokok) dalam ahlus sunnah wal jama'ah. Dengan tolong-menolong, maka telah terealisasikan salah satu pokok ajaran Islam.

4) Dengan saling menolong dan kerjasama, maka akan memperlancar pelaksanaan perintah Allah, membantu terlaksananya amar ma'ruf dan nahi munkar. Saling merangkul dan bergandengan tangan akan menguatkan antarasatu dengan yang lain.

5) Ta'awun melahirkan cinta dan belas kasih antara orang yang saling menolong dan menepis berbagai macam fitnah.

6) Ta'awun mempercepat tercapainya target pekerjaan, dengannya pula waktu dapat dihemat. Sebab waktu amat berharga bagi kehidupan seorang muslim.

7) Ta'awun akan memudahkan pekerjaan, memperbanyak orang yang berbuat baik, menampakkan persatuan dan saling membantu. Jika dibiasakan, maka itu akan menjadi modal kehidupan sebuah ummat. ${ }^{26}$

\section{Manajemen Dana Iuran Rukun Kematian Di Puntun Kota Palangka Raya}

Mengelola atau memanajemen suatu dana haruslah menerapkan unsur-unsur yang terdapat dalam manajemen, agar dana tersebut dapat digunakan sebagaimana mestinya, mengenai manajemen dana iuran rukun kematian di Puntun Kota Palangka Raya:

1) Planning (Perencanaan)Dana Iuran Rukun Kematian di Puntun Kota Palangka Raya.

\footnotetext{
${ }^{24}$ M.Quraish Shihab, Berbisnis dengan Allah, Tanggerang: Lentera Hati,2008.h.146-147.

${ }^{25}$ Departemen Agama, Al-Qur'an dan Terjemahnya..., h.157

${ }^{26}$ Sumber https://iahsolikhah.wordpress.com/2011/04/12/ta\%E2\%80\%99awun-dan-israf/o. diakses tanggal 21 mei 2016.
} 
Berkaitan dengan planning atau rencan pihak RKM harus menerapkan unsur manajemen ini untuk keberlangsungan RKM tersebut, seperti dijelaskan oleh saudara YY bahwa untuk sekarang ini mereka belum mempunyai suatu rencana atau program-program khusus, karena pada saat ini mereka masih berfokus untuk menstabilkan keuangan yang mereka miliki, kemudian saudara YY menambahkan lagi, bahwa pada awalnya mereka memang mempuyai rencana untuk membeli mobil ambulan, namun recana tersebut ditunda karena setelah melihat keadaan keuangan yang terus menurun dan dengan keadaan keuangan seperti itu tidak memungkinkan pihak RKM untuk melanjutkan rencana pembelian mobil ambulan.

Menurut penulis rencana pihak RKM untuk menggunakan sebagian dana iuran yang tersisa untuk membeli ambulan sangat bagus, mengingat ambulan tersebut dapat digunakan oleh pihak RKM untuk membantu membawa jenazah. Hal ini pun dapat mengurangi biaya pengurusan jenazah, karena selama ini untuk transportasi ambulan pihak RKM menggunakan mobil ambulan yang terdapat di mesjid terdekat, dan itu pun harus mengeluarkan biaya untuk membayar ambulan tersebut. Akan tetapi, rencana mereka ingin membeli ambulan tersebut tertunda dikarena keadaan keuangan yang mereka miliki mengalami penurunan, sehingga untuk sementara ini pihak RKM tidak berani mengambil rencana-rencana atau program-program lain dan saat ini mereka masih berfokus untuk menstabilkan keuangan mereka dengan cara menaikkan uang iuran menjadi 10.000"

2) Organizing(mengatur) dana iuran rukun kematian di Puntun

Agar rencana penggunaan dana dapat berjalan dengan lancar maka rencana tersebut harus diatur dengan sebaik mungkin, seperti yang seperti yang dijelsakan oleh saudara saudara YY bahwamereka mengatur dana iuran seperti biasa, mereka akan mengadakan iuran apabila ada salah satu anggota yang mendapat musibah. Kemudian, sisa dari iura tersebut akan mereka masukkan kedalam kas, yang mana kas tersebut mereka simpan di bank muamalat. Akan tetapi, saat ini keuangan mereka sedang mengalami penyusutan, sehingga mereka mensiasati penyusutan tersebut dengan menaikkan uang iuran. Kemudian saudara YY menambahkanbahwa uang yang disampan dibank tersebut atas nama saudara YY, yang mana uang tersebut baru digunakan apabila uang kas yang ada di saudara YY tidak cukup untuk memberikan santunan kepada anggota yang mengalami musibah. Kemudian YY menjelaskan lagi bahwa mereka memiliki kategori dalam memberikan santunan yaitu kategori anak-anak mendapatkan 1.500.000, kemudian dewasa mendapatkan 2.000.000.

Menurut penulis tindakan pihak RKM menikkan uang iuran memang perlu dilakukan, mengingat pada saat ini harga barang untuk keperluan mengurus jenazah mengalami kenaikkan. Selain itu, dengan menaikkan uang iuran ini agar apa yang direncanakan oleh pihak RKM dapat dicapai, yang mana pihak RKM berencana menggunakan sebagian dana yang terkumpul untuk membeli mobil ambulan. Selain itu, tindakan pihak RKM menikkan uang iuran merupakan suatu strategi dari pihak RKM agar dana yang mereka miliki mengalami kenaikkan dan tidak mengalami penyusutan secara terus-menerus. Hal ini sesuai dengan fungsi manajemen yaitu organaizing atau pengaturan yang mana pengaturan ini sangat diperlukan dalam sebuah manjemen karena pengaturan ini dapat membantu agar pelaksanaan dari suatu recana dapat dicapai secara efektif dan ekonomis. 
3) Actuating (menggerakkan atau kepemimpinan)

Agar planning dan organizing dapat berjalan lancartentunya semua pihak harus bekerjasama terutama dalam pengelolaan keuangan, kemudian agar keuangan tersebut tidak mengalami penyusutan terus-menerus, maka salah satu upaya pihak RKM yaitu dengan menikkan uang iuran kemudian pihak RKM juga selalu mengingatkan anggota yang terlambat untuk membayar iuran wajib yang dilakukan setiap ada musibah meninggal dunia. Seperti yang dijelaskan oleh saudara NR bahwa apabila ada anggota RKM yang terlambat membayar uang iuran maka tindakan yang dilakukan oleh pihak RKM yaitu dengan cara menghubungi anggota yang bersangkutan melalui via telefon dan pihak RKM meminta agar anggota yang bersangkutan segera melunasi iuran yang menunggak. Namun, apabila setelah ditelefon anggota tersebut tetap tidak membayar maka akan diberhentikan. Hal tersebut sama dengan pernyataan saudara YY bahwa"hal tersebut sudah jelas didalam peraturan bahwa apabila terlambat membayar uang iuran sebanyak lima kali maka akan diberhentikan"

Menurut penulis tindakan yang dilakukan oleh pihak RKM dengan cara menghubungi anggota yang terlambat membayaran dan diberhentikan jika tetap tidak membayar uang iuran apabila sudah diperingati perlu dilakukan dan hal ini sesuai dengan fungsi manajemen yaitu actuating (menggerakkan atau kepemimpinan) yang mana fungsi manajemen ini bertujuan untuk mengajak atau mengarahkan para anggotanya untuk mencapai tujuan, hal tersebut juga dilakukan untuk menjaga keberlangsungan RKM. karena jika anggota tersebut tidak membayar uang iuran maka pihak RKM juga akan kesulitan memberikan santunan kepada anggota yang mengalami musibah.

4) Controlling (Pengendalian atau pengawasan) dana iuran rukun kematian di puntun

Mengenai pihak yang mengawasi RKM tersebut seperti pernyataan saudara YY bahwa mereka tidak memiliki lembaga khusus untuk mengawasi mereka namun mereka mempunyai seorang tokoh sebagai penasehat untuk pengurus RKM tersebut.

Menurut penulis, pihak RKM perlu mempunyai suatu lembaga khusus untuk dijadikan sebagai pengawas dalam RKM yang mereka kelola, hal ini bertujuan agar apa yang mereka kerjakan dapat berjalan dengan lancar terlebihnya dalam pengelolaan keuangan dan program-program kerja yang mereka rencanakan.

\section{Praktik Pemberian Dana Iuran Rukun Kematian di Puntun berdasarkan prinsip ta'awun.}

Islam sebagai adhien jama' ${ }^{27}$ yang berarti mengutamakan kerja sama dalam menyelesaikan berbagai permasalahan untuk mencapai suatu keberhasilan. Konsep kerja sama dalam masyarakat merupakan fardhu kifayah atau sebagai kewajiban bersama yang harus dilaksanakan. ${ }^{28}$ Berikut pemaparan berdasarkan wawancara terhadap beberapa subyek mengenai pemberian dana santunan rukun kematian dipuntun. Pertama penulis menayakan bagaimana sistem pemberian santunan, seperti yang dijelaskan oleh saudara MI bahwapada awalnya sistem pemberian santunan yang dilakukan oleh mereka yaitu dengan cara

\footnotetext{
${ }^{27}$ Adhien jama' $i$ adalah sekelompok manusia yang berhimpun bekerja sama untuk mencapai tujuan yang sama.

${ }^{28}$ Abdullah Amrin, Meraih Berkah Melalui Asuransi Syariah: Ditinjau dariPerbandingan dengan Asuransi Konvensional, Jakarta: Gramedia, 2011.h.74.
}

Jirhanuddin., Dakhoir,Ahmad., dan Sulistyaningsih/ Jurnal Al-Qardh, Vol. 2, No. 5, Desember (2016) 
membelikan peralatan untuk keperluan anggota yang meninggal. namun seiring berjalannya waktu ada ketidakpercayaan anggota terhadap pengurus RKM, sehingga pihak RKM memutuskan memberikan santunan berupa uang dengan jumlah yang ditentukan.

Menurut penulis pemberian uang santunan secara langsung lebih baik dari pada membelikan peralatan untuk anggota yang mendapatkan musibah, hal ini untuk mengantisipasi terjadinya kecurigaan para anggota terhadap pengurus RKM. Hal ini sesuai dengan manajemen Islam yang sangat memperhatikan keterbukaan, kerena berkaitan dengan nilai kejujuran, pengelolaan yang sehat, dan terbuka (open minded) atau transparansi. ${ }^{29}$ Sikap jujur, amanah dan terbuka dalam mengelola dana sesuai dengan firman Allah SWT yang berbunyi:

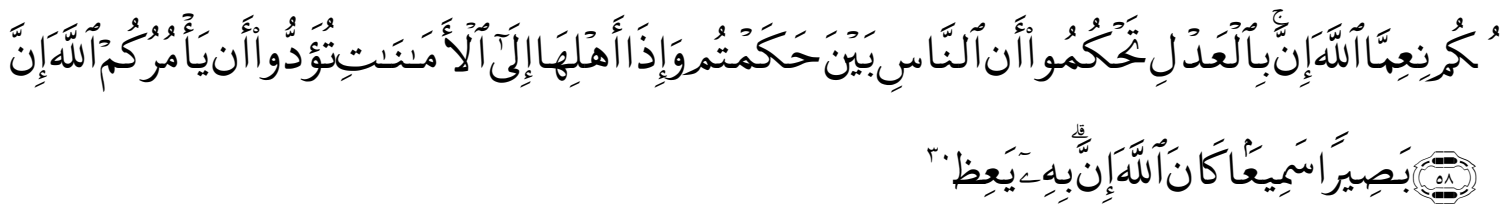

Artinya:"Sesungguhnya Allah menyuruh kamu menyampaikan amanat kepada yang berhak menerimanya, dan (menyuruh kamu) apabila menetapkan hukum di antara manusia supaya kamu menetapkan dengan adil. Sesungguhnya Allah memberi pengajaran yang sebaik-baiknya kepadamu. Sesungguhnya Allah adalah Maha mendengar lagi Maha melihat.”(QS.An-Nisa ayat 58)

Kemudian mengenai pemberian santunan terhadap anggota baru dan anggota lama, bahwa menurut saudara NR tidak ada perbedaan antara anggota lama dan anggota baru, berikut pernyataan saudara NR bahwa tidak ada perbedaan antara anggota baru dan anggota lama. Anggota yang baru mendaftar apabila terjadi musibah anggota tersebut bisa langsung mendapatkan santunan dan hal ini sesuai dengan anjuran dalam agama Islam agar umat Islam berbuat kebajikan, saling bekerja sama dan tolong-menolong dalam perkara-perkara yang baik serta dalam meningkatkan ketakwaan. Saling bekerja sama dan tolong-menolong dalam bentuk harta merupakan salah satu perbuatan yang sangat dicintai oleh Allah SWT karena hal itu akan membawa kepada kesejahteraan dan kemakmuran kaum muslimin seluruhnya. Bentuk dan cara untuk saling bekerjasama dan tolong-menolong dalam hal harta benda seperti zakat, sodaqoh, hibah yang semuanya didasarkan atas niat ikhlas semata-mata demi untuk mendapatkan keridhaan Allah SWT tanpa mengaharapkan balasan dari harta yang telah diberikan. ${ }^{31}$

Namun hal tersebut berbeda dengan apa yang dijelaskan oleh saudara MI bahwa anggota yang baru mendaftar harus melewati jangka waktu tiga bulan baru bisa mendapatkan santunan, jika sebelum tiga bulan mendapatkan musibah keluarga anggota tersebut tidak bisa menerima santunan dari pihak RKM. Kemudian hal tersebut juga sama dengan pernyataan YY bahwa anggota yang baru masuk harus melewati jangka waktu tiga bulan, jika mendapat musibah sebelum jangka waktu tiga bulan maka pihak keluarga tidak bisa menerima santunan, mereka menerapkan peraturan seperti itu karena pihak RKM tidak mau dibohongi oleh anggota yang hanya menginginkan dana RKM, selanjutnya juga YY menyatakan

\footnotetext{
${ }^{29}$ Syarifuddin, Manajemen Lembaga Pendidikan Islam,...h.

${ }^{30}$ Depertemen Agama, Al-Qur'an dan Terjemahnya ...,h.128

${ }^{31}$ Nurul Ichsan Hasan, Pengantar Asuransi Syariah, Jakarta: Referensi (Gaung persada Press Group),2014.h.72.
} 
pernah terjadi ketika ada warga yang baru pindah ke Puntun, kemudian warga tersebut mendaftar sebagai anggota RKM, tidak beberapa lama kemudian anggota tersebut meninggal dan pihak keluarga dari anggota tersebut menuntut hak yaitu berupa santunan. Namun, dikarena anggota tersebut belum melewati batas waktu yang ditentukan maka pihak RKM tidak memberikan dana santunan kepada keluarga anggota tersebut. Kemudian saudara MI menyatakan bahwa mereka tidak memberikan santunan terhadap anggota baru sebelum tiga bulan terdapat dalam peraturan RKM, meskipun peraturan tersebut tidak tertulis atau terlampir dalam buku keanggotaan. Namun anggota RKM mengetahui bahwa peraturan tersebut diberlakukan, bahkan apabila ada warga yang ingin menjadi anggota RKM, maka pihak RKM akan menjelaskan Mengenai peraturan-peraturan yang diberlakukan di RKM tersebut.

Menurut penulis berdasarkan pernyataan saudara YY dan MI mengenai pemberian santunan terhadap anggota yang baru mendaftar harus melewati jangka waktu tiga bulan terlebih dahulu baru bisa menerima santunan kurang tepat. Terlebih lagi hal tersebut memang menjadi peraturan yang diberlakukan didalam RKM, karena jika dilihat peraturan seperti ini sangat bertentangan dengan tujuan utama didirikannya RKM. Seharusnya peraturan tersebut tidak diterapkan dalam RKM, sebab pada dasarnya RKM ini dibentuk untuk membantu meringankan beban keluarga yang ditinggalkan. RKM ini pun bersifat nonprofit atau tidak mencari keuntungan dan hal ini berbeda dengan BPJS ataupun asuransi yang bersifat profit atau mencari keuntungan.

Berkaitan dengan tolong-menolong atau ta'awun, menurut penulis seharusnya pihak RKM tetap memberikan bantuan atau santunan kepada anggota baru yang mendapat musibah, jika pihak RKM tidak bisa memberikan santunan kepada anggota baru dengan penuh setidaknya pihak RKM memberikan santunan sedikit agar dapat membantu meringankan beban keluarga yang ditinggalkan, karena anjuran untuk saling tolong-menolong tercantum dalam firman Allah SWT dalam QS al-Maidah ayat 2.

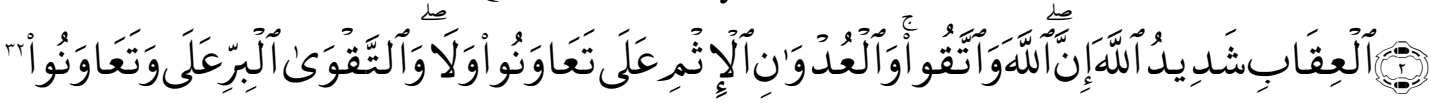

Artinya:"Dan tolong-menolonglah kamu dalam (mengerjakan) kebajikan dan takwa, dan jangan tolong-menolong dalam berbuat dosa dan pelanggaran. dan bertakwalah kamu kepada Allah, Sesungguhnya Allah Amat berat siksa-Nya.”

Ayat 2 di atas juga memberi izin berburu selama telah menyelesaikan ibadah ritual haji atau umrah. Lebih jauh, ayat tersebut memperingatkan bahwa kebencian yang telah mencapai puncaknya sekalipun kepada sesuatu kaum tidak boleh mendorong untuk berbuat aniaya kepada mereka atau selain mereka. Hal ini dipertegas dengan perintah tolongmenolong dlam kebajikan dan ketakwaan serta melarang kerja sama dalam kedurhakaan. ${ }^{33}$ Selain itu, dengan ayat ini, manusia dituntun oleh Allah SWT agar selalu tolong-menolong (ta'awun) antar sesamanya dalam kebaikan dan didasari atas nilai takwa kepada Allah SWT. Hal ini merupakan suatu prinsip dasar yang harus dipegangi manusia dalam menjalani

\footnotetext{
${ }^{32}$ Depertemen Agama, Al-Qur'an dan Terjemahnya..., h.157.

${ }^{33}$ M.Quraish Shihab, Al-Lubab Makna Tujuan dan Pelajaran dari Surah-Surah al-Qur'an, Tanggerang:Lentera Hati,2012.h. 249-250.
} 
kehidupannya di atas permukaan bumi ini. Dengan saling melakukan tolong-menolong (ta'awun), manusia telah menjalankan satu fitrah dasar yang diberikn Allah SWT. ${ }^{34}$

Perintah bertolong-tolongan dalam mengerjakan kebaikan dan takwa adalah termasuk pokok-pokok petunjuk sosial dalam Al-Qur' an. Karena ia mewajibkan kepada manusia agar saling memberi bantuan satu sama lain dalam mengerjakan apa saja yang berguna bagi umat manusia, baik pribadi maupun kelompok, baik dalam perkara agama maupun dunia, juga dalam melakuka setiap perbuatan takwa, dengan hal tersebut mereka dapat mencegah terjadinya kerusakan dan bahaya yang mengancam keselamatan mereka. ${ }^{35}$ selain itu perintah tolong-menolong atau meringankan beban sesama muslim merupakan anjuran Nabi Muhammad SAW yang terdapat dalam hadis Nabi :

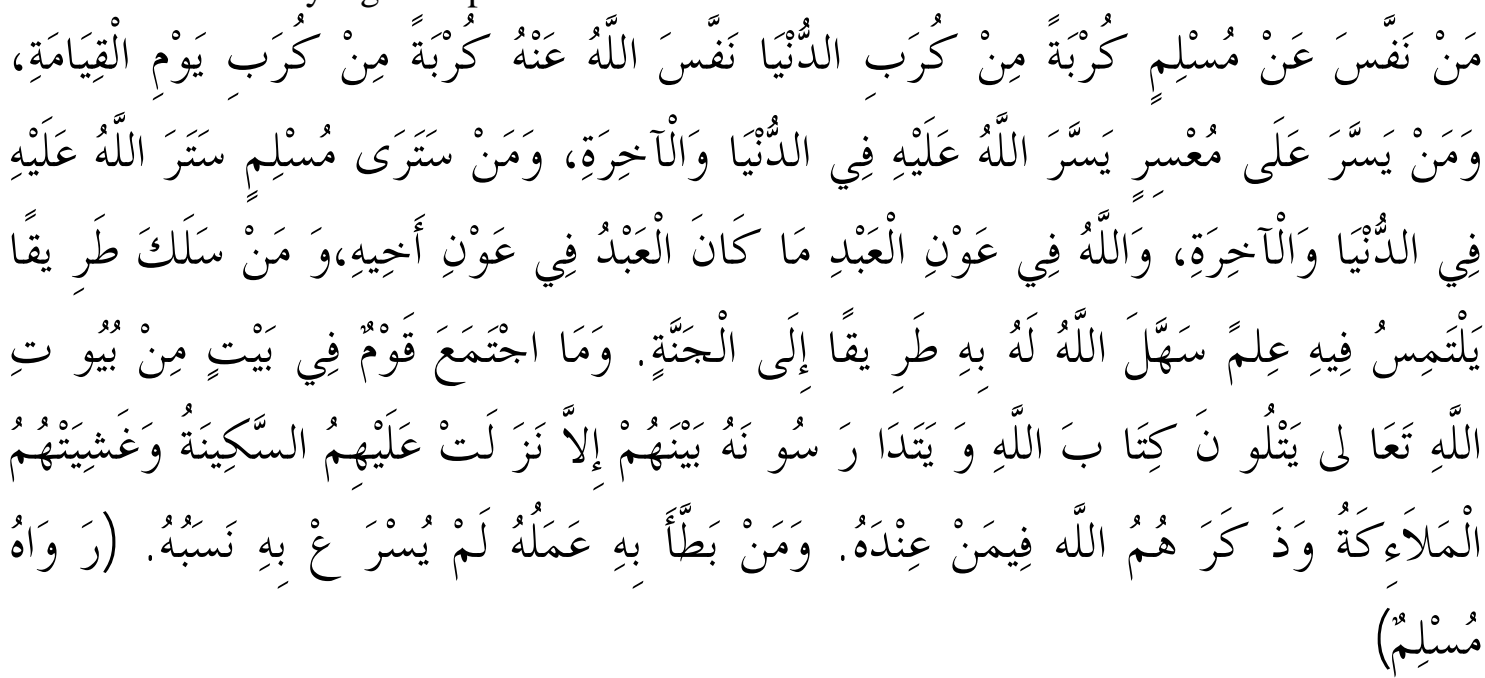

Artinya:"Barangsiapa melapangkan kesusahan di antara kesusahan-kesushan seorang mukmin di dunia, maka Allah akan melapangkan untuknya satu kesusahan di antara berbagai kesusahannya pada hari kiamat. Barangsiapa yang memberikan kemudahan kepada seorang yang kesukaran, maka Allah akan memberikan kemudahan kepadanya di dunia dan di akhirat. Barang siapa menutupi cela seorang muslim, maka Allah akan menutupi celanya di dunia dan di akhirat. Allah itu selalu memberikan pertolongan kepada hamba-Nya, selama hamba itu memberikan pertolongan kepada saudaranya. Barangsiapa menempuh jalan untuk suatu ilmu, maka Allah akan memudahkan untuknya jalan menuju surga. Tiadalah suatu kaum itu berkumpul dalam suatu rumah di antara rumah-rumah Allah untuk membacakan kitab Allah dan saling mengajarkannya di antara mereka, melainkan ketenangan hati turun kepada mereka, rahmat Allah menutupi mereka, dan para malaikat mengelilingi mereka. Allah menyebut-nyebut mereka di kalangan makhluk yang ada

\footnotetext{
${ }^{34}$ AM.Hasan Ali, Asuransi Dalam Prespektif Hukum Islam,...h.98-100.

${ }^{35}$ Ahmad Mushthafa Al-Maraghiy, Terjemahan Tafsir Al-Maraghiy 6, Semarang: Toha Putra,
} 1987.h.81

Jirhanuddin., Dakhoir,Ahmad., dan Sulistyaningsih/ Jurnal Al-Qardh, Vol. 2, No. 5, Desember (2016) 
di sisi-Nya. Barangsiapa lambat amalnya, maka ia tidak bisa dipercepat oleh nasabnya." (HR.Muslim) ${ }^{36}$

Adapun faedah atau manfaat dari ta'awun adalah sebagai berikut:

8) Dengan tolong-menolong, pekerjaan dapat diselesaikan dengan lebih sempurna. Sehingg jika ada kekurangan, maka yang lain dapat menutupinya.

9) Dengan ta'awun dakwah akan lebih sempurna dan tersebar.

10) Ta'awun dan berpegang teguh kepada al-jama'ah adalah perkara ushul (pokok) dalam ahlus sunnah wal jama'ah. Dengan tolong-menolong, maka telah terealisasikan salah satu pokok ajaran Islam.

11)Dengan saling menolong dan kerjasama, maka akan memperlancar pelaksanaan perintah Allah, membantu terlaksananya amar ma'ruf dan nahi munkar. Saling merangkul dan bergandengan tangan akan menguatkan antarasatu dengan yang lain.

12) Ta'awun melahirkan cinta dan belas kasih antara orang yang saling menolong dan menepis berbagai macam fitnah.

13) Ta'awun mempercepat tercapainya target pekerjaan, dengannya pula waktu dapat dihemat. Sebab waktu amat berharga bagi kehidupan seorang muslim.

14)Ta'awun akan memudahkan pekerjaan, memperbanyak orang yang berbuat baik, menampakkan persatuan dan saling membantu. Jika dibiasakan, maka itu akan menjadi modal kehidupan sebuah ummat. ${ }^{37}$

\section{E. Penutup}

Berdasarkan hasil penelitian yang penulis lakukan penulis menemukan bahwa manajemen pengelolaan dana RKM yang berada di Puntun belum sepenuhnya menerapkan prinsip-prinsip manajemen yang terdiri dari Planning, Organizing, Actuating, dan Controlling. kemudian praktik pemberian santunan yang dilakukan oleh pihak RKM Gotong Royong belum sepenuhnya menerapkan prinsip ta'awun yang menjadi prinsip utama dibentuk nya RKM ini. Hal ini dapat dilihat ketika pihak RKM memberikan jangka waktu 3 bulan terhadap anggota yang baru mendaftar, apabila sebelum jangka 3 bulan anggota baru tersebut mendapat musibah (meninggal dunia) maka anggota tersebut tidak berhak menerima santunan dari pihak RKM.

\section{F. DAFTAR PUSTAKA}

Abdurrahman , Nana Herdiana, Manajemen Bisnis Syariah \& Kewirausahaan, Bandung: Pustaka Setia, 2013

.Al-Bugha, Musthafa Dib, Syarah Riyadhush Imam an-Nawawi, Jakarta: Gema Insani.2010. Alma, Buchari \& Donni Juni Priansa, Manajemen Bisnis Islam, Bandung: Alfabet, 2014. Al-Maraghiy, Ahmad Mushthafa, Terjemahan Tafsir Al-Maraghiy 6, Semarang:Toha Putra Al-Husaini, Imam Taqiyudin Abu Bakar, Kifayatul Ahyar Jilid I, Surabaya: Bina Ilmu, 1997. Amrin, Abdullah, Meraih Berkah Melalui Asuransi Syariah: Ditinjau dari Perbandingan dengan Asuransi Konvensional, Jakarta: Gramedia, 2011. 2010.h.436.

${ }^{36}$ Musthafa Dib al-Bugha, Syarah Riyadhush Shalihin Imam an-Nawawi, Jakarta:Gema Insani,

${ }^{37}$ Sumber https://iahsolikhah.wordpress.com/2011/04/12/ta\%E2\%80\%99awun-dan-israf/o. diakses tanggal 21 mei 2016.

Jirhanuddin., Dakhoir,Ahmad., dan Sulistyaningsih/ Jurnal Al-Qardh, Vol. 2, No. 5, Desember (2016) 
Athoillah, H.M Anton, Dasar-dasar Manajemen, Bandung: Pustaka Setia.2013. Aziz, Abdul, Manajemen Investasi Syariah, Bandung: Pustaka Alfabeta, 2010.

Depertemen Agama, Al-Qur'an dan Terjemahnya, Semarang :Tanjung Mas Inti Semarang, 1992.

Hafidhuddin, Didi \& Hendri Tanjung, Manajemen Syariah dalam Praktik, Jakarta:Gema Insani Press, 2003

Hasan, Nurul Ichsan, Pengantar Asuransi Syariah, Jakarta: Referensi (Gaung persada Press Group), 2014

Muhammad, Manajemen Dana Bank Syariah, Yogyakarta: Ekonisia, 2005.

Shihab, M.Qurais, Al-Lubab Makna Tujuan dan Pelajaran dari surah-surah Al-Qur'an, Tanggerang: Lantera Hati.2012.

Shihab, M.Qurais, Berbisnis Dengan Allah, Tanggerang: Lentera Hati.2008.

Siswanto, H.B, Pengantar Manajemen, Jakarta: Bumi Aksara.2011.

Syafaruddin, Manajemen Lembaga Pendidikan Islam, Ciputat: Ciputat Press, 2005.

Sula, Muhammad Syakir, Asuransi Syariah Konsep dan Sistem Operasional, Jakarta: Gema Insani, 2004

Soemitra , Andri, Bank \& Lembaga Keuangan Syariah, Jakarta: Kencana Prenada Media Group, 2014 